\title{
Front Matter: Volume 10204
}

, "Front Matter: Volume 10204," Proc. SPIE 10204, Long-Range Imaging II, 1020401 (21 June 2017); doi: 10.1117/12.2270676

SPIE. Event: SPIE Defense + Security, 2017, Anaheim, CA, United States 


\section{PROCEEDINGS OF SPIE}

\section{Long-Range Imaging II}

Eric J. Kelmelis

Editor

11 April 2017

Anaheim, California, United States

Sponsored and Published by

SPIE 
The papers in this volume were part of the technical conference cited on the cover and title page. Papers were selected and subject to review by the editors and conference program committee. Some conference presentations may not be available for publication. Additional papers and presentation recordings may be available online in the SPIE Digital Library at SPIEDigitallibrary.org.

The papers reflect the work and thoughts of the authors and are published herein as submitted. The publisher is not responsible for the validity of the information or for any outcomes resulting from reliance thereon.

Please use the following format to cite material from these proceedings:

Author(s), "Title of Paper," in Long-Range Imaging II, edited by Eric J. Kelmelis, Proceedings of SPIE Vol. 10204 (SPIE, Bellingham, WA, 2017) Seven-digit Article CID Number.

ISSN: 0277-786X

ISSN: 1996-756X (electronic)

ISBN: 9781510609099

ISBN: 9781510609105 (electronic)

Published by

SPIE

P.O. Box 10, Bellingham, Washington 98227-0010 USA

Telephone +1 3606763290 (Pacific Time) · Fax +1 3606471445

SPIE.org

Copyright @ 2017 , Society of Photo-Optical Instrumentation Engineers.

Copying of material in this book for internal or personal use, or for the internal or personal use of specific clients, beyond the fair use provisions granted by the U.S. Copyright Law is authorized by SPIE subject to payment of copying fees. The Transactional Reporting Service base fee for this volume is $\$ 18.00$ per article (or portion thereof), which should be paid directly to the Copyright Clearance Center (CCC), 222 Rosewood Drive, Danvers, MA 01923. Payment may also be made electronically through CCC Online at copyright.com. Other copying for republication, resale, advertising or promotion, or any form of systematic or multiple reproduction of any material in this book is prohibited except with permission in writing from the publisher. The CCC fee code is $0277-786 \mathrm{X} / 17 / \$ 18.00$.

Printed in the United States of America.

Publication of record for individual papers is online in the SPIE Digital Library.

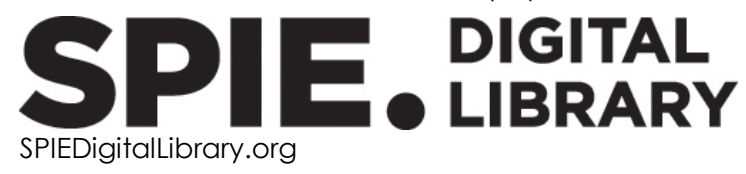

Paper Numbering: Proceedings of SPIE follow an e-First publication model. A unique citation identifier (CID) number is assigned to each article at the time of publication. Utilization of CIDs allows articles to be fully citable as soon as they are published online, and connects the same identifier to all online and print versions of the publication. SPIE uses a seven-digit CID article numbering system structured as follows:

- The first five digits correspond to the SPIE volume number.

- The last two digits indicate publication order within the volume using a Base 36 numbering

system employing both numerals and letters. These two-number sets start with 00, 01, 02, 03, 04, $05,06,07,08,09,0 A, O B \ldots$. OZ, followed by 10-1Z, 20-2Z, etc. The CID Number appears on each page of the manuscript. 


\title{
Contents
}

\author{
$\checkmark$ Authors \\ vii Conference Committee
}

\section{SESSION 1 IMAGING SYSTEMS}

1020402 Spline warp model for registering pushbroom multispectral imagery [10204-1]

1020404 A comparison of optical architectures for constrained long-range imaging [10204-3]

1020405 PyBSM: A Python package for modeling imaging systems (Rising Researcher Paper) [10204-4]

\section{SESSION 2 APPLICATIONS}

1020406 UAV imagery analysis: challenges and opportunities (Invited Paper) [10204-5]

1020408 Photo-acoustic and video-acoustic methods for sensing distant sound sources [10204-7]

\section{SESSION 3 TURBULENCE MODELING AND MITIGATION I}

1020409 Comparing multiple turbulence restoration algorithms performance on noisy anisoplanatic imagery [10204-8]

10204 0A Quantifying the improvement of turbulence mitigation technology [10204-9]

$10204 \mathrm{OB}$ On the simulation and mitigation of anisoplanatic optical turbulence for long range imaging [10204-10]

10204 0C Development of an embedded atmospheric turbulence mitigation engine [10204-11]

\section{SESSION 4 TURBULENCE MODELING AND MITIGATION II}

10204 OE Enhancement of DARPA SRVS data with a real-time commercial turbulence mitigation software [10204-13]

10204 OF Open source acceleration of wave optics simulations on energy efficient highperformance computing platforms [10204-14]

10204 OG Anisoplanatic image propagation along a slanted path under lower atmosphere phase turbulence in the presence of encrypted chaos [10204-15] 
Proc. of SPIE Vol. 10204 1020401-4

Downloaded From: https://www.spiedigitallibrary.org/conference-proceedings-of-spie on 26 Apr 2023 Terms of Use: https://www.spiedigitallibrary.org/terms-of-use 


\section{Authors}

Numbers in the index correspond to the last two digits of the seven-digit citation identifier (CID) article numbering system used in Proceedings of SPIE. The first five digits reflect the volume number. Base 36 numbering is employed for the last two digits and indicates the order of articles within the volume. Numbers start with 00, 01, 02, 03, 04, 05, 06, 07, 08, 09, OA, OB...0Z, followed by 10-1Z, 20-2Z, etc.

Beck, Jeffrey, OF

Bonnett, James, OA, OC

Bos, Jeremy P., OF

Chatterjee, Monish R., OG

Dapore, Alexander J., 09

Egan, Matthew D., 02

Eismann, Michael T., 05

Espinola, Richard L., OE

Gittins, Christopher M., 02

Goodman, Timothy D., 04

Grant, Barbara G., 06

Hardie, Russell C., 09, OB

Kelmelis, Eric, 08, OA, OC, OE

Kozacik, Stephen, 08, OA, OC, OE

LeMaster, Daniel A., 05, OB

Mohamed, Ali A., OG

Olson, S. Craig, 04

Paolini, Aaron, OA, OC, OE

Rucci, Michael A., 09

Saquib, Suhail S., 02

Sherman, Ariel, OA, OE

Slater, Dan, 08

Sparks, Andrew W., 04

Wheeler, Craig S., 04 
Proc. of SPIE Vol. 10204 1020401-6

Downloaded From: https://www.spiedigitallibrary.org/conference-proceedings-of-spie on 26 Apr 2023 Terms of Use: https://www.spiedigitallibrary.org/terms-of-use 


\section{Conference Committee}

Symposium Chair

Donald A. Reago Jr., U.S. Army Night Vision \& Electronic Sensors

Directorate (United States)

Symposium Co-chair

Arthur A. Morrish Raytheon Space and Airborne Systems

(United States)

Conference Chair

Eric J. Kelmelis, EM Photonics, Inc. (United States)

Conference Program Committee

Jeremy P. Bos, Michigan Technological University (United States)

Chris J. Cormier, Raytheon Company (United States)

Vincent Hamel, L-3 Wescam (Canada)

Daniel A. LeMaster, Air Force Research Laboratory (United States)

Jony Jiang Liu, U.S. Army Research Laboratory (United States)

Craig Olson, L-3 Communications (United States)

Kevin Rice, UTC Aerospace Systems (United States)

Session Chairs

1 Imaging Systems

Stephen Kozacik, EM Photonics, Inc. (United States)

2 Applications

Michael Rucci, U.S. Air Force (United States)

3 Turbulence Modeling and Mitigation I

Kevin Rice, UTC Aerospace Systems (United States)

4 Turbulence Modeling and Mitigation II

Aaron L. Paolini, EM Photonics, Inc. (United States) 
Proc. of SPIE Vol. 10204 1020401-8

Downloaded From: https://www.spiedigitallibrary.org/conference-proceedings-of-spie on 26 Apr 2023 Terms of Use: https://www.spiedigitallibrary.org/terms-of-use 